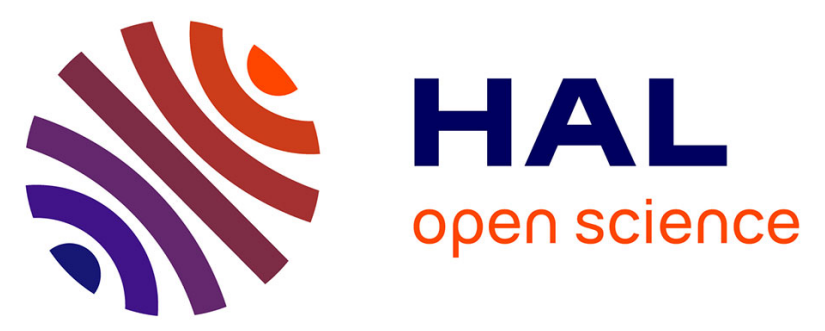

\title{
National Industrial Relations Systems and Cross-border Restructuring: Evidence from a Merger in the Pharmaceuticals Sector
}

Tony Edwards, Xavier Coller, Luis Ortiz, Chris Rees, Michael Wortmann

\section{- To cite this version:}

Tony Edwards, Xavier Coller, Luis Ortiz, Chris Rees, Michael Wortmann. National Industrial Relations Systems and Cross-border Restructuring: Evidence from a Merger in the Pharmaceuticals Sector. European Journal of Industrial Relations, 2006, 12 (1), pp.69-87. 10.1177/0959680106061369 . hal00570947

\section{HAL Id: hal-00570947 \\ https://hal.science/hal-00570947}

Submitted on 1 Mar 2011

HAL is a multi-disciplinary open access archive for the deposit and dissemination of scientific research documents, whether they are published or not. The documents may come from teaching and research institutions in France or abroad, or from public or private research centers.
L'archive ouverte pluridisciplinaire HAL, est destinée au dépôt et à la diffusion de documents scientifiques de niveau recherche, publiés ou non, émanant des établissements d'enseignement et de recherche français ou étrangers, des laboratoires publics ou privés. 
( 2006 SAGE (London, Thousand Oaks, CA and New Delhi)

Volume 12 Number 1 pp 69-87 www.sagepublications.com

\title{
Tony Edwards, Xavier Coller, Luis Ortiz, Chris Rees and Michael Wortmann
}

Kings College London, UK, Georgetown University, USA, Universitat Pompeu Fabra, SpaIN, Kingston University, UK and

Wissenschaftszentrum Berlin, GeRMANY

\section{National Industrial Relations Systems and Cross-border Restructuring: Evidence from a Merger in the Pharmaceuticals Sector}

\begin{abstract}
This article examines the restructuring process following a cross-border merger in the pharmaceuticals sector. We show how national industrial relations systems account for some aspects of cross-national differences in the process and outcomes of restructuring. However, we also argue that institutionalist approaches to comparative analysis must be complemented by a focus on the material interests of organizational actors and the resources that they can deploy.

KEYWORDS: national industrial relations systems - restructuring cross-border mergers - multinationals - pharmaceuticals
\end{abstract}

\section{Introduction}

There is much evidence that national industrial relations (IR) systems constrain the behaviour of multinational companies (MNCs): distinctive laws, regulations, and customs create 'host country effects' which lead them to adapt their approach to managing labour to national contexts (Rosenzweig and Nohria, 1994). However, the literature also indicates that subsidiaries are often under pressure from the corporate centre to adopt practices from the home country, the so-called 'country of origin effect'. MNCs often possess the strength and resources to establish new 'rules of the game' in host business systems (Djelic and Quack, 2003: 24), and Geary and Roche (2001: 124) argue that the weight of evidence points to 'the predominance of country of origin effects over host country effects'.

Cross-border mergers and acquisitions (M\&As) and the consequential changes in the scale of the operating units and the structures into which 
they are organized (the 'restructuring process') provide an important test of this argument. There is often a marked shift in management strategy and style in the acquired firm, bringing new industrial relations policies. Rationalization programmes aimed at achieving cost-savings through removing duplicate operations intensify the pressures to comply with corporate expectations. Yet by definition, firms engaging in cross-border M\&As confront pre-existing employment practices; they have less scope for innovation than in greenfield sites.

This article examines the post-merger period in a pharmaceuticals multinational, focusing on the restructuring process in four comparable plants in very different national industrial relations systems: the USA, the UK, Germany, and Spain. We consider, in particular, how far unions and works councils in these countries constrained management, leading to differing outcomes across borders. We investigate a number of employment policies that were pushed by the centre, particularly job regrading. We find that national regulations and institutions presented only partial constraints upon how MNCs engaged in restructuring. We therefore argue that analysis must include a political perspective.

In the next section, we explain the key concepts guiding our analysis and discuss our research methods. We then provide some detail on the four sites and their fortunes after the merger, exploring the similarities and differences. We show that these patterns can be explained in part by distinctive national institutional contexts, but that a political approach, focusing on how actors promote or defend their interests, is also necessary. The conclusion draws together the findings and their implications for further analysis.

\section{Conceptual Framework and Methods}

A growing literature addresses the impact on MNCs of national institutional frameworks, arguing that the rules and norms that characterize business systems are the basis of enduring national differences. The 'embeddedness' of MNCs in their original home base shapes the way that acquiring firms manage the workforces in the acquired units (Aguilera and Dencker, 2006; Faulkner et al., 2002). This is consistent with a wider literature that emphasizes the 'country of origin effect' in management style in MNCs (Ferner et al., 2004).

National institutions are also the source of 'host country effects' in cross-border M\&As. For example, Corteel and Le Blanc (2001) conclude from a series of case studies of Franco-German mergers that 'social issues' (pay, working time, holidays, pensions, and so on) are governed by a 'national logic'. Since differences between the French and German operations that existed prior to the mergers persisted thereafter, the 
authors claim that these are 'lastingly rooted at national level'. They go to some lengths to emphasize the role of the barriers at national level that MNCs face in restructuring their operations.

Institutionalist approaches insist that national differences endure because national institutions respond only slowly to changing economic conditions. However, national systems may vary in their 'resilience' to external challenges, and also in their resistance or receptiveness to the introduction of novel practices that are not well embedded domestically.

Studies have demonstrated such differences in 'receptivity' in the four countries considered in our research. The US system, with low union membership and minimal legal support for forms of employee representation, allows MNCs considerable freedom in restructuring. Studies of foreign MNCs in the USA have demonstrated the ease with which they have been able to introduce a range of employment practices that depart from pre-existing norms (Katz and Darbishire, 2000). The British system also exhibits significant receptivity, particularly because of the sharp reduction in union presence and influence in the past quarter of a century. For example, the literature demonstrates the major changes in work organization pioneered by many Japanese MNCs (Elger and Smith, 1994).

This receptivity also shows up in the more regulated Spanish context. Employee representation structures are quite patchy, and while Spain has a complex web of legal regulations that ostensibly constrain the ability of MNCs to introduce new practices, their impact is limited. In a study of a food multinational, Coller shows that despite the ordenanza laboral requiring workers moved to a higher-grade job to be paid the upgraded rate, the 'effect of this constraint was minor so long as local managers had ways of adapting the law to their needs' (1996: 163), which they did through moving production workers to new posts for sufficiently short periods.

Even in Germany, Wever (1995: 622) argues that 'there is considerable room for the development of organizational styles that may be inconsistent with local norms and traditions'. Accordingly, performance- or profit-related pay and employee share-ownership have become common in MNCs in Germany. Kurdelbusch (2002) presents data showing that these have been implemented even within firms that engage in codetermination and collective bargaining.

A challenge for institutionalist approaches is to account for the agency of actors within MNCs. Since host-country institutions do not wholly determine how MNCs operate, we must also focus on the politics of organizations in order to understand how restructuring occurs. Crossborder M\&As are inherently political since many key issues, such as the nature of a rationalization programme, affect the fortunes of a number of organizational groups, who will advance their own interests using whatever resources they control. Hence, a focus on how groups of actors 
advance or protect their own interests is a necessary complement to an institutional analysis (Wailes et al., 2003).

One contested issue is the extent of control over operating units exercised by actors at the corporate headquarters (HQ), who may value a high degree of control to enhance their own legitimacy and to facilitate their restructuring plans. They control a number of important resources, such as the allocation of investment funds and the promotion of managers at lower levels; and since most cross-border M\&As lead to the removal of duplicate functions and the closure of some sites, their ability to decide where these cuts fall is a particularly important source of power.

In contrast, actors in the operating units may resist enhanced central control. Retaining a high degree of autonomy sustains the status of local managers and may also allow them to devise practices consistent with the national business system in which they are embedded. Managers at this level also possess a number of resources, such as locally generated expertise and contacts with key customers, allowing them to bargain with HQ over the extent of central control. Central management will never have perfect information concerning the practices in operation at all of their subsidiaries, creating scope for units to deviate from corporate polices; should such deviations come to light eventually, they will subsequently seek to explain and justify this. Subsidiary managers may also openly challenge the logic of a corporate policy and operate quite different practices from those favoured by the HQ, engaging in 'active resistance' and perhaps forming coalitions across operating units to challenge corporate policies through 'concerted action'.

In summary, an emphasis on national institutions must be complemented by a focus on the strategies of organizational actors. Institutions set constraints within which political activity within firms can operate, shaping the preferences of actors and the feasibility of certain courses of action, but they do not determine outcomes on their own. This is the basis on which we explore how far the restructuring process in our casestudy firm was shaped by nationally distinct patterns of industrial relations. National constraints might be at their strongest during and after cross-border M\&As because regulations specific to M\&As bolster the role of industrial relations institutions, limiting the scope of management action. Conversely, these constraints may be particularly weak following a cross-border merger since the uncertainty concerning where cuts will fall makes actors in the operating units more accommodating to HQ requests than at other times.

One of the main strengths of case studies is that they can address why and how linkages between various phenomena occur and how these evolve (Yin, 2002: 10). The comparative case-study method allows analysis of the reaction of actors who face similar pressures, but operate in quite distinct national contexts. In selecting a firm, we sought a 'critical 
case' (Bélanger et al., 1994) from among companies that were part of the first phase of a wider research project on cross-border M\&As (Rees and Edwards, 2003). The case-study firm, which we call 'PharmaCo', was created through a 'friendly' merger of a British and a predominantly US firm of roughly equal size and was selected because initial interviews indicated that the merger had brought a marked change in management style.

Many mergers are justified on the basis that a shake-up of existing structures and practices can lead to an acquired unit operating more efficiently, but cross-border ones can also involve a new national influence. Before the PharmaCo merger, the approach of the US firm to human resources was relatively centralized, while the British one was largely decentralized. The initial research indicated that the corporate human resource (HR) function in the merged firm became very influential, developing a number of international policies, and that this mirrored the structure of the US party that had possessed 'globally integrated businesses and functions'. As one respondent put it, while it was initially 'communicated as a merger of equals', it was evident that those from the US firm were 'driving the bus', particularly in HR.

This resulted in a number of corporate policies that applied across sites, many of these modelled on initiatives in the US part of the company. Some, such as those relating to diversity, merely constituted broad statements of principles. In other areas, there was greater compulsion on sites to implement practices mandated by $\mathrm{HQ}$, such as policies on the use of 'contingent' workers, pay and performance management, regrading of jobs into common categories, and new forms of work organization.

Pressure to operate at lower costs was felt to some extent by all sites, but the impact of a strong, controlling HQ was new only to those belonging to the British firm. Our research design, therefore, focuses on four plants out of approximately 60 that had belonged to the British firm, and examines the impact of this pressure in the two and a half years following the merger. Since the four host countries possess notable differences in industrial relations systems, we are able to examine the extent to which the dominant national institutions constrained the restructuring.

The four countries selected differ considerably in the regulation of employment issues in M\&As in particular and in the key features of their national industrial relations system in general. In all three European countries, there is a requirement (stemming from, or reinforced by, the EU Acquired Rights Directive) for basic terms and conditions of employment to be protected and for consultation with worker representatives before a merger goes ahead, with this basic framework being supplemented with additional institutions at national level. In contrast, the USA has much weaker regulations concerning M\&As: employers must consult their workforces only if a merger leads to collective 
redundancies, while changes to terms and conditions are conditioned only by union contracts (where they apply) and individual contracts of employment.

Perhaps more important when considering post-merger restructuring are the institutions and regulations that are key features of the national system and may restrict management's ability to introduce new practices. The diversity across countries shows up very markedly in the coverage of collective bargaining, which is highest in Germany and Spain, has fallen sharply in the UK, and is very low in the USA. The level of bargaining also varies significantly, being predominantly sectoral in Germany, at a mixture of levels in Spain, and at company or workplace level in the UK and USA. Significant differences are also evident in workplace-based forms of employee representation, which are most influential in Germany, moderate in Spain, weak in the UK, and weakest of all in the USA.

We began our fieldwork by conducting 12 interviews, between nine and 18 months after the merger, at the HQ (which is split between the USA and the UK) in order to establish the nature of the restructuring process as planned by senior management. Subsequently, between 18 and 30 months after the merger, we examined the impact of the restructuring process at site level (six interviews in the UK, five each in Germany and Spain, and four in the USA). We also interviewed five respondents in units, mainly research and development, that were not based at HQ, but had linkages with the sites. We used an interview schedule with some flexibility to allow unanticipated issues to be pursued, revising this iteratively during the course of the research to reflect new findings, but retaining a core set of questions. All 37 interviews were recorded and transcribed, and many were undertaken by multiple interviewers from across countries.

The constraints of access meant that the team relied on only one respondent for some categories of actors. However, we feel that the data have many strengths, not least that there is a neat symmetry across research sites and that these were similar in terms of basic technologies, yet were located in markedly different national industrial relations systems. Our collective familiarity with the four national systems meant that we were sensitive to similarities and differences between the respondents' views. The data possess breadth, ranging across different units and using similar methods in each, and depth, deriving from a range of levels within the firm.

\section{Restructuring in the Four Sites}

A key task facing corporate management immediately after the merger was to identify where cutbacks should occur. The pharmaceuticals sector 
has overcapacity in manufacturing, and the merger had been justified to shareholders partly as offering scope for cost-cutting in the manufacturing division. However, one constraint was the difficulty in serving a national market without a manufacturing presence in that country: many national health systems, generally government controlled and regulated, prefer to buy medicines that are locally produced. Before the merger, each firm had kept open sites in small markets that operated well below full capacity. Afterwards, however, the duplication of sites facilitated closures; central management aimed to close a third of the sites and to make the surviving plants more specialized in production.

All sites were classified as 'new product introduction' sites, 'mature product' sites (high-volume products protected by a patent), or 'tail-end product' sites (drugs that had patents close to expiry). One of the key factors that shaped this categorization was the extent to which sites enjoyed regulatory approval to produce a lucrative drug for key markets. Firms must gain approval from the regulatory body (normally national, though increasingly at EU level for member states) to sell in a particular market, and this approval is plant specific; sites that have the necessary capacity and expertise to comply with the demanding requirements of these regulators are in a favourable position.

All four sites we investigated were relatively secure in this respect. The US site possessed approval from the Federal Drugs Agency (FDA) for some of the company's best-selling drugs, earning it the status of a secure 'mature product' site. The UK site, similarly, had regulatory approval for several major drugs in Britain and elsewhere and had become a 'new product introduction' site. The Spanish and German sites were exporters of a range of drugs that required regulatory approval from government agencies in a number of markets, and both had 'mature product' status. All four sites, therefore, were relatively safe and employment was stable or rising. Since each of the four sites enjoyed secure mandates and relatively stable employment, we could focus on one specific aspect of restructuring: the influence of a more active corporate centre as against local isomorphism reflecting distinctive national systems of industrial relations.

A key contextual factor in restructuring across countries was the nature of employee representation, and this is summarized in Table 1. The non-union status of the US plant and the well-organized and apparently influential works council in Germany were in line with what might be expected given the nature of the national system. The British plant had well-embedded unions, also consistent with a broader national pattern in large, mature manufacturing plants. However, the Spanish plant, though in a sector with strong unions, had no union involvement in its works committee (comité de empresa) and was not typical in this respect. To what extent can the operation of the four HR policies that we focus on 


\section{TABLE 1. Employee Representation at the Four Sites}

\begin{tabular}{|c|c|}
\hline Germany & $\begin{array}{l}\text { The site is party to the collective agreement in the chemicals } \\
\text { sector that sets basic pay rates. In addition, the works council is } \\
\text { well organized and has exerted significant influence over many } \\
\text { employment policies. }\end{array}$ \\
\hline
\end{tabular}

Spain The site follows the collective agreement for the chemicals sector, which covers a diverse range of sub-sectors (such as oil derivatives and fertilizers) and sets only minimum levels of pay that the site exceeds considerably. There is a works committee, but trade unions are unrepresented despite numerous attempts to organize the site. This may be due in part to a 'welfare capitalist' management approach.

UK Two main unions are recognized, each representing different occupational groups. Density is around 60 percent, and a shop steward system is the main channel for day-to-day contact with the unions. Collective bargaining over pay and conditions takes place exclusively at site level.

USA No organized employee representation at the site.

be understood through the lens of these differing IR contexts? We consider each of these in turn.

Following the merger, corporate HQ sought to influence job classifications in the operating units, particularly for grades above middle managers and senior professionals, through the introduction of a global grading system. As one respondent at HQ put it:

Wherever you are in the world your job will be graded in a global scheme and if you're at a certain band in the organization that will attract certain benefits ... If you're from [the British firm] that's very new. You would have been entirely based on whatever the local country terms and conditions would have been, now suddenly you have these global things into which you have no input.

In the US plant, the exercise led to financial losses for some employees; approximately 30 professional and managerial workers lost entitlement to stock options; but job insecurity and the lack of collective representation meant that there was little concerted opposition. As the site HR director put it: 'it's probably something of not wanting to speak up too loudly and voice up a negative, there are enough positions being eliminated in the future ... and of course it's a non-union plant so there is no channel that way'. In contrast, there was no evidence of equivalent professional grades in the German and British sites losing out as a consequence of regrading. In these two sites, the vast majority of employees, 
including professionals and some managers, are covered by collective agreements.

However, the process of recategorizing jobs had important similarities across the four sites: most obviously, creating identical job categories among professionals and managers. Moreover, the sites appeared to have implemented regrading enthusiastically, with some respondents stressing the benefits in terms of the increased mobility of staff across sites. In sum, on this issue all sites were receptive to the introduction of the new system, but the variations in the industrial relations context shaped the consequences for individual employees.

A second area of significant central influence was work organization. This took the form of the adoption of the 'Lean Sigma' system, a particular approach to analysing work processes. This had two principal elements: an attempt to reduce the number of steps in the manufacturing process, and a move to identify and reduce mistakes and defects. This initiative had clearly come from the USA; one British respondent put it like this:

Well, [the firm of consultants who introduced it] is American. And all their consultants are American. So you get sent on a five-day course and you are trained by Americans, the people that are assigned as experts are trained by Americans and you get this American coming over to tell you how to do it. It is very American. And it is sponsored by [the head of manufacturing] who is American.

There was some evidence of flexibility in the implementation of Lean Sigma. Once a site had adopted the system, it was then up to actors at this level to operate it. In particular, there was considerable freedom to identify appropriate cost-saving measures. Accordingly, sites were able to implement changes that went with the grain of their industrial relations context.

Nonetheless, there were some striking similarities in the way that Lean Sigma operated. Sites appointed a 'champion' who took overall responsibility for the initiative, and were all close to the target of having 1 percent of staff trained as 'experts'. Given severe pressure to reduce costs, all four sites had engaged actively in Lean Sigma. Significantly, there was frequent inter-site collaboration on its use, and sharing of many initiatives. Overall, the findings are consistent with those on job regrading: the design of Lean Sigma allowed some adaptation to the national context, but despite this, there were strong similarities in how it operated.

A third area in which the corporate HQ exerted pressure was the use of temporary workers. All sites used a sizeable 'contingent' workforce of temporary and agency workers to cope with fluctuations in demand. Shortly after the merger a legal ruling in the USA stipulated that workers with more than 18 months' continuous service must be afforded the same 
pay and benefits as other workers. This had clear implications for US sites, but somewhat surprisingly, a corporate directive preventing sites from using temporary workers for this length of time also applied to British sites.

UK managers found themselves in a difficult position. The ruling had no legal relevance for them. Moreover, the site faced considerable fluctuations in demand as it received new mandates for some products and lost others. Managers at this level argued that they were being forced to lay off productive and reliable temporary workers in order to comply with a legal ruling that did not cover their site; thus, they opposed the policy, arguing that it made it difficult to meet production targets. Eventually, as we will see in more detail in the next section, the policy was relaxed to allow a temporary exclusion for the British site.

Overall, the findings on this issue cannot be fully understood with reference to national institutions. The policy on the use of contingent workers certainly arose from US institutions, but its implementation in Britain cannot be seen as an adaptation to host country effects; outside the USA, the policy was applied only to the UK and not to Germany or Spain, yet the 18-month threshold had no legal basis in any of the three countries.

The fourth issue that we consider is variable pay. Central HR managers pushed hard for operating units to increase the significance of performance-related pay (PRP). The norms of the US and British systems, where PRP is more widespread than in most other countries, clearly shaped the firm's international policy on this issue. As one respondent at HQ put it: 'we are saying to our sites "if the norm in your country was that 10 percent of pay is at risk, we would expect you to have 15 percent. In other words, we want you to be at the top end of the pay for performance element."”

In relation to pay more generally, the influence of distinct national systems is clearly evident; levels of pay and its composition differ significantly across countries. Most obviously, there was no attempt to harmonize pay rates across quite different labour markets. Many other aspects of terms and conditions, such as sickness pay and holiday entitlement, were left to local management to set in line with local labour markets. For PRP itself, there was also evidence that national context shaped its operation. In Germany, for instance, management initiated discussions concerning an individualized component of pay, but the works council argued that it ran counter to the practice of group work and used its legal powers to limit the use of PRP to relatively senior grades.

However, as Table 2 confirms, there were also many common elements to the way that 'variable' pay was implemented. In all four cases, the site bonus plan closely resembled the corporate model of using 'key performance indicators' to construct a multiplier to calculate bonuses for all staff, 
TABLE 2. Pay and Performance at the Four Sites

Germany A site bonus plan, introduced before the merger, is now calculated according to three 'key performance indicators' (trading profits, supply performance, and 'right first time' achievement). For production workers it can constitute up to 3 percent of salary on top of pre-existing pay, which remained unchanged. The works council used its legal powers to prevent individual PRP for non-managerial workers.

Spain A site bonus plan existed before the merger, but was restructured to reflect a series of 'key performance indicators'. In addition, there is individual PRP for manual workers, based on a subjective assessment by the supervisor of an employee's savoir-faire. Managerial and professional workers have pay set on an individual basis with a strong performance-related element.

UK Following the merger, a site bonus plan was introduced, determined by a range of 'key performance indicators'. For production-line workers, this is capped at 9 percent of their salary and there is no assessment of individual performance. For about half of the site (800-900 professional and managerial employees), however, there is also an 'individual personal multiplier' calculated through an appraisal process.

USA A site bonus plan which existed before the merger is now calculated on the 'key performance indicators' and can constitute a slightly higher percentage of salary than before. Pay for professionals and managers varies according to individual performance.

with individualized PRP used to supplement this for some groups. These similarities occurred despite the variations in context.

Moreover, where there were significant differences, these were not easily explained by differences in national industrial relations systems. In the UK, Germany, and the USA, the link between individual performance and pay covered only a subset of employees at the site, generally those of managerial and professional grades. In Spain, however, this link predated the merger and existed for all employees, albeit affecting only a small percentage of pay (generally less than 1 percent for most workers). The performance-related element was contingent on the employee's appraisal on issues such as willingness to work on Saturdays and potential for promotion. It is not easy to understand in terms of national industrial relations systems why the Spanish plant had the practice for all workers, but the British and US sites did not. Similarly, the variations in 
the proportion of total pay constituted by the site bonus could not easily be explained in this way.

One relevant factor is the location of the Spanish site. Martínez Lucio (1998: 445) notes that one of the key aspects of collective bargaining in Spain is that the 'bargaining effectiveness of union organization varies widely between provinces and regions'. While the sector is the main formal level of bargaining, more than twice as many employees are covered by 'provincial-sectoral' agreements than 'national-sectoral' agreements; and where, as in pharmaceuticals, the national agreement remains predominant, the constraints it imposes on individual workplaces are limited. The pharmaceuticals industry is covered by the chemicals sector agreement, which includes a diverse range of firms: oils, paints, lubricants, and so on. The Spanish plant of PharmaCo was, in practice, not significantly affected by it; located in a rural, largely agricultural region where unions have traditionally been weak (Fuhrer, 1996: 121-4), the representative arrangements that are necessary to provide meaningful bargaining at local level are, in Martínez Lucio's (1998: 445) terms, 'inoperative'. Thus, employee representation at the site presented little in the way of constraints to implementing new practices: while there is a works committee, unions have repeatedly failed to have their nominees elected and the principal employee representative is a relatively senior manager. Consequently, the council appears to have little influence in challenging management's plans. Other pharmaceuticals sites are generally located in urban areas, particularly around Madrid and Barcelona, and have significant union involvement at workplace level.

Hence national systems can only partially explain the findings in the four policy areas. Moreover, the tenor of respondents' views concerning the growing influence from the corporate HQ differed across sites in a way that was slightly counter-intuitive. We might have expected greater concern about a strong US influence over international HR policies in the regulated and distinctive German and, to a lesser extent, Spanish contexts than in the more deregulated British and US systems, but the reverse was the case: interviewees in Britain and the USA were notably more critical of the corporate HQ than in Spain and Germany. Care must be exercised in interpreting this evidence, but at the very least, it suggests the need to extend our analysis beyond national industrial relations institutions if we are to understand the restructuring process.

\section{Political Activity}

A political approach, focusing on the differences of interest between organizational actors and the way these are resolved through the exercise of power, can complement the institutional approach. This approach 
addresses the discretion possessed by actors at site level within the policy constraints set by higher levels of management. As argued earlier, senior HQ management may seek to control operating units in order to execute their restructuring plans and enhance their own status. Both factors were in evidence in PharmaCo. The cost-cutting drive that followed the merger required corporate policies to dictate the process. While this was accepted as proper and legitimate by all of our respondents, many argued that HQ influence had developed a 'momentum of its own'. As noted earlier, this view was particularly widespread at the British and US sites, but even one HQ respondent admitted that the initially clear boundaries between areas controlled by HQ policy and those left to operating units had become blurred.

Some degree of discretion is almost always deliberately afforded to sites. While PharmaCo's management style was centralized, the corporate HR function did not try to exert complete control over the sites since this would involve significant costs, such as the risk of stifling innovation across the firm. An example was the limiting of job regrading to certain occupational groups in order to minimize implementation problems. The extent of local discretion varied, however, across sites. HQ exercised greater control over the US and British sites because they constitute such a critical mass of production and because of the basic compatibilities between the two business systems. As Child et al. (2001) have argued, US firms are likely to seek to reproduce their core values and associated practices in acquired units in business systems with strong similarities with the USA, but less so in different business systems, such as Spain and Germany. One respondent claimed that 'the interesting dynamic in PharmaCo is there is a lot of focus on the US and the UK ... so we spend a lot of time and energy on the US-UK issues and a big piece of [the division] is left untouched'. In consequence, some policies, such as that relating to the employment of 'contingent' workers, affected these sites, but not others.

Variations also stemmed from the political manoeuvring of actors at site level, who implemented many corporate policies enthusiastically, but perceived others as threats to their interests. As discussed above, local managers within MNCs may value autonomy from the HQ since it allows them to develop an influential position within their business units and 'go with the grain' of the business system in which they are located. Such autonomy sometimes results from the failure of HQ to communicate corporate guidelines effectively. For example, during one interview the HR director of a site examined a booklet of corporate policies in order to check the details of one particular issue. As he did so, he found other written guidelines about which he was unaware, and therefore evidently not following. But in addition to such unintentional deviation from corporate policies, there was evidence from respondents at both site 
and HQ level that local managers sometimes deliberately went 'behind the back' of the HQ. As one corporate manager put it, 'I think what in reality happens is a little different from what we think might happen.'

This was less likely to occur in areas that HQ monitored closely; but even here, site managers can maximize their discretion by simply ignoring a corporate policy, having to justify their actions only if discovered. As one UK respondent argued, 'it's easier to beg forgiveness after the event than it is to ask for permission to do it in the first place'. Autonomy can also be created by the 'active resistance' of local managers, some of whom openly challenged the logic of corporate policies. An example was evident in the use of temporary staff. One of the main preoccupations of the HR director at the UK site was to adjust staffing levels to fluctuations in demand; following the merger, it received product transfers from other sites and employment rose by around 30 percent. Management knew that employment would fall back as other products were transferred elsewhere; but corporate policy not to use temporary staff continuously for more than 18 months became a major constraint, since a number of reliable temporary workers would have to be discharged. The site HR director failed to persuade corporate HR that the policy should be relaxed, but ultimately he managed to gain a temporary exemption by making a plea to the director of the manufacturing division, who overruled the corporate HR function.

Such resistance to corporate HR policies can be an important source of variation between plants. In PharmaCo, as we have seen, one important source of power at site level is regulatory approval to sell drugs in national markets. Since the British site produced six of the 10 best-selling drugs in the company, and was one of a very small number of 'new product introduction' sites, it was in a powerful position to challenge HQ. This was an important factor in its ability to gain exemption from the corporate policy on contingent workers. Since the power of sites to resist corporate policies varies, actual practice will vary also.

A further illustration of how the interests and power of actors at site level leads to variations in the extent of resistance is their response to the new corporate policies on 'variable' pay. As we have seen, HQ required sites to implement PRP and bring their use of share options into line with corporate guidelines. Despite this clear challenge to the interests of a significant number of professional staff at the US site, resistance was constrained both by the climate of potential redundancies and the lack of formal representative structures. In contrast, in Germany the works council blocked management's initial proposals for individual PRP. The system eventually implemented involved a 'top-up' to basic pay that did not depend on individual performance and was not therefore seen as challenging employees' interests. Evidently, the ability of actors to resist corporate policies is shaped by the institutional context in which they are embedded. 
Resistance can also stem from actors across sites taking concerted action. The company identified five key regions and established management structures around these. Such regional structures provide fertile ground for micro-political processes, potentially reducing the influence of corporate policies. After the merger many actors sought defence against the stronger central influence, and regional structures facilitated this, since they had some potential to mediate or circumvent corporate policies. For example, the HR director for European manufacturing described his role, in part, as helping the sites fend off the growing weight of corporate policies: 'there is so much that happens, the sites just get flooded with [corporate policies]. I am the sort of barrier to stop that happening, so I see myself as in the position of pushing back on these things as well.'

Another illustration of regional alliances was in North America, where our case-study site was secure, but had pre-existing close relations with another that was vulnerable. The safe site helped out the more vulnerable one, as the HR director for North American manufacturing put it, by 'ensuring that we have them at the front end of any leading edge initiatives' within the region so that it is 'viewed as a mover and a shaker on a key corporate initiative'. Perhaps more importantly, bilateral agreements to transfer production across sites within the region were taken partly to help 'ensure the survival' of the vulnerable plant. This ran counter to the corporate programme of closing sites.

Ferner et al. (2004: 380) have argued that European HR structures in US MNCs 'provided national subsidiaries with a common voice and a means of interest aggregation vis-à-vis central $\mathrm{HR}$, and there were indications that [the European HQ] could align itself with the subsidiaries, fighting central proposals on their behalf'. We found one such case in our study, involving explicit defiance of corporate policies in respect of a pay deal for a site identified for closure. To gain exemption from an acrossthe-board ceiling on pay rises, the European HR director worked in concert with the site HR team to argue for a three-year pay deal in excess of the corporate ceiling. This was initially overruled by corporate HR, but the team appealed directly to the president of the manufacturing division with a 'business case' for exemption, stressing the danger of ' $a$ threat to continuity of supply' through possible industrial action. An exemption was granted.

\section{Conclusion}

The article has considered the strength of host-country effects in the face of strong centralizing pressures. National industrial relations institutions clearly present significant constraints on MNCs and how they restructure 
following a cross-border merger. In extreme cases, such as occurred at Corus (EIROnline, 2003), restructuring plans can be vetoed by employee representatives. More generally, the embeddedness of MNC workplaces in distinct, host business systems means that many employment practices are adapted to the local context.

However, national systems presented only partial constraints to PharmaCo management, even on issues such as payment systems and job regrading that are strongly shaped by institutional factors. Thus, while national industrial relations systems partially condition the actions of MNCs, they also exhibit a degree of receptivity. Actors at corporate level often control sufficient resources to override host-country effects, while the decisions on where precisely within a country the operations should be located can be motivated by a desire to minimize the constraints of national systems. Consequently, the restructuring that follows crossborder M\&As is only partly governed by a 'national logic'.

Thus, in explaining how the restructuring process occurred in PharmaCo, we have highlighted the utility of a 'national institutionalist' approach, but also its limitations. Differences in structures of employee representation, the handling of 'social issues', the job-regrading process, and policies on 'variable' pay could to some extent be explained by national industrial relations systems; but this explanation needs to be complemented by a focus on the material interests of organizational actors and the resources available to advance their interests. Indeed, institutional and political approaches are not merely complementary, they must be seen as interdependent: as we have seen, the ability of actors to resist corporate policies that challenge their interests is shaped by the institutional context in which they are embedded.

There are, of course, some limitations to our analysis. First, we examined sites that fared well from the restructuring process. It is possible, indeed likely, that we would have uncovered a different story at others that were suffering cutbacks. These more vulnerable sites would have been less able to resist central influence, so we do not claim that the outcomes at the sites we described would be matched across the entire company. However, we feel that this is not a major limitation; if the aim is to investigate the impact of central pressure on sites, then it makes sense to focus on core sites where the corporate HQ is likely to devote most effort to applying its polices, rather than on those that are marginal to the firm's future. Second, the findings may be sector specific. One of the peculiarities of pharmaceuticals is the system of product regulation, which gives sites considerable power within the firm. Of course, in all sectors there are important sources of power that reside at site level (contacts with customers, knowledge of the local context, expertise in particular technologies, and so on), but it is quite possible that these are more significant in pharmaceuticals than in many others. A further reason 
why the findings may be different in other sectors concerns the variations we have noted in the strength of employee representation structures. In the car industry, management would find it much more difficult to keep trade unions out of the workers' committee in Spain, for example.

The issues raised here could usefully be examined in more detail in future research. The theme of the article, that national industrial relations systems present only partial constraints to MNCs, demands further and more detailed examination. One line of enquiry could consider highly institutionalized systems as not only constraining, but also facilitating innovation. One example of this is the training system in Germany, which relies on a range of extra-firm institutional supports and equips employees with broad, adaptable skills that enable them to operate some practices, such as job rotation within teams, that their more narrowly skilled counterparts in other countries may be unable to perform. This may make them more 'open' to the transfer of practices requiring such skills. Thus, the question at the heart of this article may be turned on its head: do more regulated and densely institutionalized industrial relations systems facilitate the introduction of some corporate policies during restructuring that their more deregulated counterparts struggle to accommodate?

\section{ACKNOWLEDGEMENTS}

We would like to thank Ruth Aguilera, Roberto Garvia and two anonymous reviewers of this journal for helpful comments on an earlier draft.

\section{REFERENCES}

Aguilera, R. and Dencker, J. (2006) 'The Role of Human Resource Management in Cross-Border Mergers and Acquisitions', International Journal of Human Resource Management (forthcoming).

Bélanger, J., Edwards, P. and Haiven, L. (1994) Workplace Industrial Relations and the Global Challenge. Ithaca, NY: Cornell University Press.

Child, J., Faulkner, D. and Pitkethly, R. (2001) The Management of International Acquisitions: Realizing Their Potential Value. Oxford: Oxford University Press.

Coller, X. (1996) 'Managing Flexibility in the Food Industry: A Cross-National Comparative Case Study in European Multinational Companies', European Journal of Industrial Relations 2(2): 153-72.

Corteel, D. and Le Blanc, G. (2001) 'The Importance of the National Issue in Cross-Border Mergers', Paper to the conference on Cross Border Mergers and Employee Participation in Europe, Ecole des Mines, Paris, March.

Djelic, M. and Quack, S. (2003) 'Theoretical Building Blocks for a Research Agenda Linking Globalization and Institutions', in M. Djelic and S. Quack (eds) Globalization and Institutions: Redefining the Rules of the Economic Game, pp. 15-34. Cheltenham: Edward Elgar. 
EIROnline (2003) 'Corus's UK Workforce Faces Deep Job Cuts', URL (March 2003): http://www.eiro.eurofound.eu.int/2003/03/feature/uk0303105f.html.

Elger, T. and Smith, C. (eds) (1994) Global Japanization? Convergence and Competition in the Organisation of the Labour Process. London: Routledge.

Faulkner, D., Pitkethly, R. and Child, J. (2002) 'International Mergers and Acquisitions in the UK 1985-94: A Comparison of National HRM Practices', International Journal of Human Resource Management 13(1): 106-22.

Ferner, A., Almond, P., Clark, I., Colling, T., Edwards, T., Holden, L. and Muller, M. (2004) 'The Dynamics of Central Control: Transmission and Adaptation of "American" Traits in US Multinationals Abroad: Case Study Evidence from the UK', Organization Studies 25(3): 363-91.

Fuhrer, I. (1996) Los sindicatos en España. Madrid: Consejo Económico y Social.

Geary, J. and Roche, W. (2001) 'Multinationals and HRM Practices in Ireland: A Rejection of the "New Conformance Thesis", International Journal of Human Resource Management 12(1): 109-27.

Katz, H. and Darbishire, O. (2000) Converging Divergences: Worldwide Changes in Employment Systems. Ithaca, NY: Cornell University Press.

Kurdelbusch, A. (2002) 'Multinationals and the Rise of Variable Pay in Germany', European Journal of Industrial Relations 8(3): 325-49.

Martínez Lucio, M. (1998) 'Spain: Regulating Employment and Social Fragmentation', in A. Ferner and R. Hyman (eds) Changing Industrial Relations in Europe, pp. 426-58. Oxford: Blackwell.

Rees, C. and Edwards, T. (2003) The HR Role in International Mergers and Acquisitions. London: CIPD.

Rosenzweig, P. and Nohria, N. (1994) 'Influences on Human Resource Management Practices in Multinational Corporations', Journal of International Business Studies 25(2): 229-51.

Wailes, N., Ramia, G. and Lansbury, R. (2003) 'Interests, Institutions and Industrial Relations', British Journal of Industrial Relations 41(4): 617-37.

Wever, K. (1995) 'Human Resource Management and Organizational Strategies in German- and US-owned Companies', International Journal of Human Resource Management 6(3): 606-25.

Yin, R. (2002) Case Study Research: Design and Methods. London: Sage.

TONY EDWARDS is Senior Lecturer in International Human Resource Management in the Department of Management, King's College London. ADDRESS: Franklin Wilkins Building, 150 Stamford Street, London, SE1 9NN, UK. [e-mail: tony.edwards@kcl.ac.uk]

XAVIER COLLER is the Prince of Asturias Chair (2005-06) in the BMW Center for German and European Studies, Georgetown University. ADDRESS: Edmund A. Walsh School of Foreign Service, Georgetown University, Washington DC 20057, USA. [e-mail: xavier.coller@aya.yale.edu] 
LUIS ORTIZ is Lecturer in the Departament de Ciències Polítiques i Socials, Universitat Pompeu Fabra.

ADDRESS: Ramon Trias Fargas, 25-27, 08005 Barcelona, Spain.

[e-mail: luis.ortiz@upf.edu]

CHRIS REES is Reader in Organisation Studies at Kingston Business School, Kingston University.

ADDRESS: Kingston Hill Campus, Kingston Upon Thames KT2 7LB, UK.

[e-mail: c.rees@kingston.ac.uk]

MICHAEL WORTMANN is a Researcher at the Wissenschaftszentrum Berlin, Abteilung Internationalisierung und Organisation.

ADDRESS: WZB, Reichpietschufer 50, D-10785 Berlin, Germany.

[e-mail: wortmann@wz-berlin.de] 